\title{
CJPS
}

\author{
Tomasz Lukaszuk
}

University of Warsaw, Poland

Fellow at Marie Sklodowska-Curie European Training Networks Global India

\section{NORMATIVE POWERS IN MARITIME AFFAIRS: INDIA-EU COOPERATION IN THE INDIAN OCEAN REGION ${ }^{1}$}

\begin{abstract}
The aim of the article is to explore how the European Union (EU) and India have developed their activities in maritime affairs, trying to boost their cooperation. The challenge for both the EU and India has been to acknowledge each other's role sin maritime affairs in the Indian Ocean Region (IOR) as a facilitator of good practices in maritime governance as well as an important ally in securing the Strategic Lanes of Communication. The main hypothesis of the article is that both the EU and India are normative powers in maritime affairs and have not yet created synergy in their activities. The growing feeling of disappointment among many countries in Asia and Europe with the Belt and Road Initiative might be used to introduce a joint EU-India program covering the same strategic intercontinental maritime lanes similar to the recent India-Japan initiative of the Asia-Africa Growth Corridor. The convergence of strategic interests of the EU and India can be materialized in the most democratic and beneficial way for both.
\end{abstract}

\section{Key words}

Indian Ocean Region, maritime governance, integrated maritime policy, normative power, the European Union, India

1 This work was supported by Marie Sklodowska-Curie European Training Network "Global India" that aims to build the knowledge and expertise required for the EU's engagement with India (www.globalindia.eu) (Grant Agreement 722446). The training network is funded by the European Commission's Horizon 2020 programme. 


\section{Introduction}

Prime Minister Narendra Modi during his visit to the UK in 2015 stated that the foreign policy of the current Indian government is the extension of domestic policy aimed at economic development and poverty eradication programs, and cooperation with the European Union (EU) as one of the most significant elements of that strategy (Modi, 2015). He characterized the EU's role in those programmes in his speech at the Raisina Dialogue Security Forum 2017 in Delhi, stressing that "with Europe, we have a vision of strong partnership in India's development, especially in knowledge industry and smart urbanization an important source of modern technologies" (Modi, 2017). Jean Claude Juncker, President of the EU, at the EU-India Summit 2017 stated that "both EU and India stand for freedom, democracy and a credible rules-based global order. We are the world's two largest democracies. We are two of the world's biggest economies. We share the same values and the belief in freedom, equality, tolerance and the rule of law. Working together with a like-minded partner like India simply makes sense. It is natural" (European Commission, 2017).

The EU countries are India's biggest trade partners (13.5\% of India's trade) and biggest foreign investors ( $€ 50$ billion). Among the ten biggest investors in India half of them are from the EU (Netherlands, Germany, France, United Kingdom and Cyprus). Six thousand EU companies employ directly or indirectly 6 million people and India is among ten biggest trade partners of the EU (Delegation of the European Union to India, 2018). Ninety per cent of trade between the EU and India is transported through Sea Lanes of Communication in the Indian Ocean region. India as the biggest littoral country of the Indian Ocean Region and as one of the most important security facilitators has its role to play. "The Indian Ocean, the third largest Ocean in the world, is perhaps the most significant of all the Oceans, being the bridge between Asia and Europe as well the economic life line of both developed and developing countries" (Singh, 2007). The Indian Ocean Region covers more than 70 million $\mathrm{km}^{2}$ with littorals inhabited by approximately a third of the world's population (Techera, 2018). In his speech at Raisina Dialogue Security Forum in 2016, the then Indian Foreign Secretary Jaishankar Subrahmanyam confirmed the change of the concept of the Indian Ocean Region by the government in New Delhi, stating that "once regarded as a maritime frontier, is today increasingly seen as a connectivity pathway. The attention that it has got from India's leadership speaks of the promise it holds in our eyes. We take a collaborative and consultative approach to the maritime domain and have initiated the Indian Ocean Naval Symposium (IONS) as well as 
the Indian Ocean Rim Association. Our twin objectives are to address common threats while unlocking the potential of the waters that join us" (Subrahmanyam, 2016).

The research centers in India and EU countries have been discussing the achievements in and challenges to cooperation in the maritime domain between the two entities, testing the implementation of joint programs and the limits of the convergence of interests. Ram (2015) pointed out the disparities in EU-India strategic partnership (in force since 2004), which omits issues strategically vital for India in the context of the competition in the Indian Ocean Region. Germond and Khurana blamed EU bureaucracy (Germond, 2015) and India's policymakers (Khurana, 2009) for "sea-blindness". Jain asserted that "the lack of a common strategic culture would continue to impede more meaningful strategic cooperation between the EU and India" (2014). Pejsova and Wilkins, while analyzing the limits of the EU-India relations, stressed that "the Indian leadership tends to view maritime security in purely conventional terms and barely acknowledges the EU as a potential partner in security matters". They argued that "Europe is fully aware of India's pressing traditional security concerns in its neighbourhood", and that "it has become globally acknowledged as a defender of a rules-based international order" (Saran et al., 2016). Permal (2014) and Singh (2019) also acknowledged the normative strength of the EU in democratic values and international law, including the law of the sea. Sachdeva and Jain criticized the EU for "the tendency to unilaterally impose its standards on the rest of the world". Examining India's activities, they stated that it "has largely pursued a reactive and defensive stance rather than a proactive one towards norms in order to safeguard its national interests and maintain a peaceful external environment to ensure development and growth" (Jain \& Sachdeva, 2019). Defending the normative dimension of the EU and India foreign policies in the Indian Ocean Region, Schoettli arrived at the conclusion that, as security providers, both of them "would like to see the consolidation of stable regimes along IOR and have made investments in the area of human security (...) through efforts to institutionalize the rule of law" (2014). Following the broader meaning of the security and India's and the EU's endeavors in IOR in that context, presented by Schoettli, the article expands the scope of the debate on EU-India cooperation, going beyond the military concept of security and maritime governance in the Indian Ocean Region. The article uses the conceptual framework of normative power to explore the strength of the EU and India not only in the context of their rule-based democratic model of development and contribution to the process of building the institutional framework in the IOR; 
it also shows their underestimated capacities in different areas of maritime governance, such as environmental protection and fishing. The research questions to be answered are how the EU and India have tried to enhance their cooperation as normative powers playing essential roles in maritime governance in the IOR, and what kind of limits they have faced in their efforts. The article argues that both the EU and India, acting as normative powers in the maritime domain, and having cooperated within the framework of the UN institutions in the second half of the 20th century, recognized the necessity to broaden their cooperation in the Indian Ocean Region in the $21^{\text {st }}$ century. They expanded the areas of cooperation into maritime security and marine environment, still seeking the ways to create synergy in response to China's growing assertiveness in the IOR. India's lack of readiness to join the naval missions beyond the UN mandate as well as the absence of the joint EU-India holistic development projects in IOR mark the limits of those efforts.

The article first discusses the concept of normative power, while the second part focuses on the EU and India as the exemplification of normative powers with different attitudes and roots. The third part explores the activities of the EU and India in maritime affairs are as a manifestation of the strength of both entities as normative powers. Finally, the article analyses cooperation between the EU and India in maritime affairs with consideration of achievements and chances for the future.

\section{The Concept of Normative Power}

The concept of normative power was developed by Ian Manners, based on the transformed concept of Europe as a civilian power by Hedley Bull (1982) and Francois Duchêne (1973). Manners primarily focused in his research on the European Community/European Union and its success in regional integration in the 1990s (Manners, 2000). In the context of the EU's normative power, he opposed extending the concept to include military capability, arguing that "the balances between short-term problem-solving and long-term structural solutions, as well as between freedom from fear and freedom from want, found in the normative policies of sustainable peace", could be lost. In his opinion, "as the EU acquires more military capability it could become more tempted to use short-term military responses instead of its traditional reliance on longterm structural conflict prevention and transformation" (Manners, 2006). In further works, he generalized the concept referring to not only the EU but also world politics (Manners, 2009). He presented the concept of normative power 
in the context of global politics at four different levels: ideational, principles, actions and impact. In his understanding, in contrast to military power, normative power in its purest form should be seen as ideational as "its use involves normative justification rather than the use of material incentives or physical force" (Manners, 2009). Normative power relations are to be "normatively sustainable" and "normatively explicable". The most important element of its strength is the legitimacy of the principles promoted, as well as coherency and consistency. Legitimacy stems from the peremptory norms of international law, conventions and universal rules recognized within the United Nations (UN) system. Norms recognized at the regional level constitute an essential source of lawfulness. The actions taken by a normative power to promote principles should be characterized by persuasion, meaning the attractiveness of arguments in favor and the presentation of choices: prestige or shame. Persuasion in the promotion of principles in world politics involves constructive engagement, the institutionalization of relations, and the encouragement of dialogue between participants. At the level of impact, socialization in the sense of the promotion of principles in world politics should play a key role. As part of an open-ended process of engagement, debate and understanding it should result in better awareness of ownership and partnership. The implementation of all the principles of normative power has consequences concerning the possibility of a more holistic, justifiable and sustainable world politics.

Thomas Diez contributed to studies on normative power arguing that it can go "alongside other forms of power in international relations, notably military and economic forms of power (...) the latter two may underpin normative power, although normative power must be irreducible to economic or military power if it is to make sense as a separate category". Additionally, normative power concept "is not confined to the EU, but includes the cases of other great powers, such as the United States" (Diez, 2005). In the context of developments in global economy after the end of the Cold War emerging powers like India and China can be mentioned. The Indian perspective on normative power was elaborated by Kavalski (2008) and Mohan (2004), presenting it after Cohen (2001) as "moralistic" and "diasporic", linked to the values based on the tradition of civilizational influence in South Asia and beyond, e.g. in Southeast Asia. While describing the profile of Indian foreign policy, Kumar emphasized that the "EU is in some ways a model" and that while "Indian goals mix realpolitik and normative elements, the means that India has used are by large within the normative framework of international law" (2008, pp. 27-28). 


\section{The EU and India as Normative Powers}

The concept of the EU as a civilian power during the Cold War developed as a natural reaction to the experience of two world wars and as an alternative to the military confrontation of the US and the Soviet Union. It also stemmed from ancient civilizational traditions of European countries like Greece as well as the Christian principles constituting the roots of values of peaceful and democratic political systems. The successful democratic transformation of Central and Eastern Europe in 1989, and the start of the accession negotiations, empowered a belief in the EU as a civilian power with influence on state model shaping at the regional level in Europe. It was transformed then to a concept of normative power, an actor in international relations showing the example of a modern model of statehood and regional integration to other countries beyond Europe. The Maastricht Treaty with the evolution of the European Community into the EU (1992) and the introduction of the EU Common Foreign and Security Policy (CFSP) enhanced its position in international relations. The implementation of common policies at bilateral and multilateral levels, including the UN, in humanitarian aid, peacekeeping, trade, and conflict prevention led to the creation of the role of the $\mathrm{EU}$ as one of the most substantial norm providers in international affairs. It included ideas of "sustainable development" and of "humanitarian intervention" coming from within the UN system, which were adopted into the EU treaty base and promoted (Manners, 2009). From the angle of methodology, that example combines the ideational level with the involvement of normative justification and legitimacy. The activities of the EU within its external relations, promoting the ideas being practiced by the EU members themselves, serve as an essential instrument of persuasion of other countries to follow the model of development. The institutionalized relations in the form of bilateral and multilateral standardized treaties and dialogue forums fulfill the socialization requirement of the normative power model creating open-ended relationships with mutual confidence of ownership and partnership.

India could have been considered as a norm provider throughout the existence of its civilization for the last six thousand years. The kingdoms of the Indian subcontinent spread Hinduism, Buddhism and Islam through peaceful means to countries further East. The traditions of the epics of Ramayana and Mahabharata became permanent elements of the culture of Southeast Asian countries, regardless their religion. The Indian diaspora in the countries of the Indian Ocean region and beyond spread the concepts of a healthy life, both physically 
and mentally, embodied in Ayurveda and Yoga. $20^{\text {th }}$ century India brought Mahatma Gandhi with his concepts of non-violence and civil disobedience which became one of the most important norm shapers of post-World War II reality. In that reality India turned out to be one of the leaders of the non-aligned movement, being an alternative to bipolar, militarized competition between the US and the Soviet Union. Through that movement India provided a powerful and coherent engine for promotion of its ideas about the principle values of ancient and modern. At the same time India was acknowledged as the most populous democratic country in the world. That act of acknowledgment supported the socialization of the Indian concept of state organization with a Western model adjusted to Eastern traditions. India's active involvement in UN institutions including peace keeping and peace-making operations enriched the consistency of the norms it promoted. In the last decade of $20^{\text {th }}$ century and the first decade of $21^{\text {st }}$, in connection with its successes in social and economic modernization benefiting from the process of globalization, India transformed itself into a model of sustainable development in the post-Cold War Global South. The network of regional political and economic institutions co-founded by India in the last thirty years supported its endeavor to impact the development of Global South states in a sustainable way according to a model of normative power.

The EU and India are normative powers on a global scale but with different activity patterns. The EU is more persuasive and assertive, while India has a more "moralistic" texture to its activities. They follow generally the same rules in promoting principles, making them coherent, holistic, and “joined-up”. For a broader promotion of norms, they use also the multilateral system at global, regional and trans-regional levels, especially the UN. Their activities in UN institutions have fostered building global consensus on key challenges for modern sustainable development such as climate change, piracy, and terrorism.

\section{EU and India Activities in Maritime Domain}

The European Community, and later the EU, has always been an active actor within the UN system in connection with issues of the maritime governance. The EU is the only international organization to be a contracting party to UNCLOS. "With Bulgaria, Germany, Greece, Italy, Netherlands, Poland and Romania, seven of the EU's 28 member states are members of the UN Ad-Hoc Committee on the Indian Ocean, which was established in 1971 to prevent Great Power rivalry in the Indian Ocean in order to enhance peace and stability in the region" (Michael, 2016). Seas and oceans are drivers for the European 
economy and have great potential for innovation and growth. The "blue" economy represents roughly 5.4 million jobs and generates a gross added value of almost $€ 500$ billion a year (Blue Growth, European Commission, 2019).

From the very beginning of its existence the EU has dealt with the sustainable use of living resources, and a common fisheries policy was included in the Treaty of Rome (1957, art. 38-43). With the further enlargement of the Community and developments within UNCLOS-III, the policy was gradually transformed and adjusted, with new regulations including the extension of rights to exclusive fishing beyond the territorial waters up to 200 nautical miles within Exclusive Economic Zones. Member countries agreed in 1983 to establish a new generation of regulatory instruments under the Common Fisheries Policy, the concept of relative stability and conservatory management measures based on total allowable catches and quotas. The European Commission played important role at the 1992 Earth Summit in Rio de Janeiro, encouraging other countries to conclude binding agreements on measures aimed at preventing further polluting of the sea and oceans, including the Convention on Biological Diversity. It contributed to the creation of Goal 14 dealing with life below water. In support of Goal 14 the EU introduced several functional and geographical platforms (they include: Cohesion policy - environment development cooperation instrument, Environment action programme, Environmental programme in Latin America, EU action plan against wildlife trafficking, EU biodiversity for life flagship initiative, European consensus on development, European development policy, European neighborhood policy, European strategy for plastic in a circular economy, Global public goods and challenges programme, LIFE biodiversity, Partnership instrument, Protecting habitats and species and Natura 2000 areas, Renewed impetus to the Africa-EU partnership), as well as linked to the fulfillment of the objectives of Agenda 21 with development assistance while concluding cooperation agreements on the Marine and coastal management, Nature action plan, Nature programmes with several developing countries. As an example the support extended by the European Community (later the EU) within the European Development Fund, to the Indian Ocean Commission, an intergovernmental organization created in 1982 in Port-Louis, Mauritius and institutionalized in 1984 by the Victoria Agreement in Seychelles (European Union External Action Service, 2016). The EU-IOC cooperation spans over various areas including environment, biodiversity, climate change, small island developing states, maritime security and the sustainable exploitation of marine fishery resources. The EU has been a leader of the integrated ocean management identified in Chapter 17 of Agenda 21, as a holistic approach towards oceans governance, by 
introducing in 2007 integrated maritime policy in a document known as the Blue Paper (Commission of the European Communities, 2007a), and a corresponding Action Plan (Commission of the European Communities, 2007b). Among the priorities of the integrated maritime policy were strengthening the position of seaports; enhancing maritime transport competitiveness; ensuring maritime safety and security; improvement of the state marine environment and coastal protection; sustainable management of marine fisheries; strengthening national energy security. The Integrated Maritime Policy (IMP) was introduced not only at the European Commission level but also incorporated into the domestic laws of member countries. Every EU member established a legal and institutional national framework of IMP. As part of the IMP, the European Commission published in 2012 the document "Blue Growth", which is the long-term strategy to support sustainable growth in the marine and maritime sectors as a whole. It is the maritime contribution to achieving the goals of the Europe 2020 strategy for smart, sustainable and inclusive growth.

The EU also became an important global player in maritime security, having introduced "Operation Atalanta" of EU NAVFOR in 2008, aimed at securing the sea lanes of communication in the western part of the Indian Ocean. Another programme, the Maritime Security Regional Program (MASE), aimed to promote safety and security at sea for the Eastern and Southern Africa, and Indian Ocean countries, was initiated in 2013. With the support of the Indian Ocean Commission, MASE has decided to create a Regional Maritime Information Fusion Centre based in Madagascar and of a Regional Coordination Centre for Maritime Operations based in Seychelles: these two centers are set up and are crucial for securing maritime areas. The EU's position of security facilitator further grew after 2014 when the new EU Maritime Security Strategy was approved. As a result, the project CRIMARIO (Critical Indian Ocean Routes) was initiated in 2015, dedicated to the Western Indian Ocean. Its main goal for the region was to help the partner countries to enhance their maritime awareness in order to reinforce safety and security at sea and to protect the marine environment.

The 1972 United Nations Conference on the Human Environment in Stockholm was a turning point in the history of environmental legislation in India. After the conference, the Indian Parliament enacted the $42^{\text {nd }}$ Constitutional Amendment Act whereby specific provisions for environmental protection were inserted in the form of fundamental duties and the National Committee on Environmental Planning and Co-ordination was established within the Department of Science and Technology (Delegation of the EU to India and Bhutan, 2006). As an active participant of UNCLOS-III (1973-1982), India defended the position of 
the developing countries on critical topics of negotiation - limitations of passage through straits, boundaries of exclusive economic zones and the continental shelf, and access to living marine resources. Before UNCLOS-III came into force, India created in 1981 a Department of Ocean Development (DOD) directly under the office of the Prime Minister (Puthucherril, 2015). The main objectives of the DOD were to promote the development of the ocean sector, to provide funds for coordination and co-operation among various existing institutions, and to support existing institutions or create new ones if necessary. After organizing a series of workshops in 1982, DOD prepared the Ocean Policy statement, discussed and adopted by the Indian Parliament in the same year. Article 4 pointed out that " $[\mathrm{t}]$ he vastness, complexity and uncertainty of the ocean environment calls for a coordinated, centralized and highly sophisticated development response". (Department of Ocean Development, 1982). The document emphasized the need for the development of ocean related science and technology linked to fishing, aquaculture, mariculture, infrastructure and the conservation of the marine environment. Regarding the use of the open ocean for cultivation of fish and other marine species, the potential area available for mariculture in India includes about 8.9 million hectares of inshore waters that can be used for open-sea farming. In 2002, DOD formulated the Vision Perspective Plan 2015. As a consequence of the enforcement of the plan, the Ministry of Ocean Development was established, soon renamed the Ministry of Earth Sciences. The competences of the new ministry were limited to weather and environmental issues. Proof of that limited portfolio is the Vision and Prospective Plan for 10 years from 2010 in Ocean Sciences and Services. It focused on the role of the ocean in the monsoon climate, routine forecasting of conditions in the Indian exclusive economic zone, natural hazards, environmental impact assessment and bio-geochemistry (Puthucherril, 2015). Other competences related to maritime governance have been assigned to many ministries and agencies at the Union level as well as at the local level from state to panchayat (village councils). That multi-layered structure of competences caused a situation where plenty of responsibilities and jurisdictions overlapped (Puthucherril, 2015). The fragmentation of competences and lack of coordination in maritime governance is a typical phenomenon among international institutions and littoral countries. India serves as an example when despite international leadership and its pioneer role, domestically it faces many challenges and problems due to that fragmentation of competences.

India was, with South Africa, the co-founder of the Indian Ocean Rim Association for Regional Cooperation (IOR-ARC) established in 1997, just five 
years after the Rio Earth Summit. IOR-ARC, transformed into IORA (the Indian Ocean Rim Association), was the first regional organization created in accordance with Goal 14 (Conserve and sustainably use the oceans, seas and marine resources for sustainable development) of Agenda 21 agreed at the Rio conference. The goals of the organization cover all the elements of maritime governance, dealing with them in a holistic way. India was also co-founder of the Bay of Bengal Initiative for Multi-Sectoral Technical and Economic Cooperation (BIMSTEC) established just a few months after IOR-ARC, with its portfolio extended beyond Agenda 21 to areas like poverty alleviation, counter-terrorism and the fight against transnational crime.

In the 21st century, India became an active player in another area of maritime governance - security. Having transformed its model of naval engagement from "brown" to "blue" waters, India made changes in its maritime doctrinal documents (maritime doctrines - 2004 and 2009, maritime military strategies - 2007 and 2015). It expanded its areas of maritime interest to the whole Indian Ocean Rim as a primary, and to the western part of the Pacific Ocean as a secondary area. The Indian Ocean Naval Symposium initiated by India in 2007 became an essential forum for 36 navies of the Indian Ocean littoral to coordinate their activities in response to natural disasters and asymmetric threats linked to illegal migration, piracy and terrorism.

The initiative of SAGAR (Security and Growth for All in the [Indian Ocean] Region), announced by Prime Minister Modi in 2015 "has set forth a proclaimed desire for India to be regarded as a promoter of collaboration and partnerships in the region and thus a supporter of multilateral initiatives. It is also a pronouncement of India's role as the region's first-responder in times of natural disaster as well as political crisis and as a net security provider" (Schoettli, 2019). SAGAR was also the symbol of India's acknowledgement of Chinese ambitions not being limited to the South China Sea but reaching across the Indian Ocean (Baruah \& Joshi, 2020).

Both the EU and India are active and significant players in maritime governance at the global and regional level. They play an important role in the creation and implementation of the UN maritime agenda within UNCLOS and Agenda 21 at domestic and regional level. One decisive element was the pressure put on the issue of the observance of the law of the sea, especially the principle of the freedom of navigation and the right to a secure passage. They provide security for sea lanes of communication. Their activities to promote Agenda 21 and to encourage countries in their particular regions and beyond them to achieve the goals of sustainable development in the maritime domain constitute one of 
the manifestations of their normative power status in global politics. They fulfill Manners' requirements at four levels: ideational, principles, actions and impact, by introducing all UNCLOS regulations into domestic law even before they came into force, then by fostering and promoting the good practices of ocean policies at domestic and regional level, furthermore by creating institutional framework, and finally by coherently and successfully encouraging other countries to follow their example.

\section{Cooperation in maritime affairs: India and the EU}

India and the EC started to cooperate in maritime affairs at the multilateral level within the Indian Ocean Fishery Commission (IOFC), established under FAO in 1967. The tuna fisheries in the Indian Ocean are the second largest in the world. Like many other regions of the world, fishing for tuna and tuna-like species in the Indian Ocean has been important to coastal communities as source of food and livelihoods throughout their history. Nowadays $69 \%$ of the catch is still taken by small scale commercial and artisanal fishing fleets (Indian Ocean Tuna Commission, 2016). Such a high percentage of catches made by small boats indicates the vital role that the issue of sustainable management of tuna stocks plays in the societies and blue economies of the Indian Ocean littoral. IOFC was partly transformed into Indian Ocean Tuna Commission (IOTC) in 1993 and the decision came into force in 1996. In 1999 IOFC was abolished and its portfolio overtook by sub-regional commissions (Southwest Indian Ocean, the Gulfs, the Asia-Pacific) and then into high-level consultations, dealing with living ocean resources other than tuna. The EU and India became the driving forces of the IOTC, whose main goals embody Agenda 21 - the conservation and optimum utilization of stocks and encouraging sustainable development of fisheries based on such stocks. Pursuant to the IOTC agreement, the Commission should also have due regard to the special interests and needs of members in the region who are "developing states" when it comes to transfer of technology, training and enhancement as well as participation in fishing. As reported to the IOTC, "India is committed to the sustainability of tuna and allied species of the Indian Ocean. India is taking all possible steps to implement the conservation and management measures." (Department of Animal Husbandry and Dairying, 2017). The IOTC endorsed many proposals on sustainable fishing tabled by the EU and India, but the performance reviews of 2007 and 2014 of the organization pointed to the fact that a wide range of measures adopted concerning conservation and 
management had turned out to be ineffective. It was agreed that the IOTC needed to be revised or replaced to allow the full participation of all fishing players and to take into account modem principles for fisheries management.

At the bilateral level, the cooperation in maritime affairs began in 1994. In their agreement on partnership and development there were several points in article 4 (economic cooperation) and article 12 (agriculture and fisheries) related to fisheries and the protection of environment. Having concluded 2004 strategic partnership agreement, the EU and India decided in 2005 in their Joint Action Plan to "work towards the conclusion of a Maritime Agreement" (India-EU Strategic Partnership. Joint Action Plan, 2005), dealing mainly with transportation issues, taking into account that $90 \%$ of the trade between the two entities was carried out by sea routes. The threats to the security of the sea lanes of communication caused by the rise of piracy next to the Horn of Africa put an impact on India's attitude towards EU security capabilities. Previously the EU's identity as a normative power was "often seen as smokescreen for shortcomings in its military capabilities and its lack of a unified security and defence policy" (Britsch, 2014). "India is eager that regional naval cooperation is not viewed as a military alliance directed at China; an advantage of EU-India cooperation is that European involvement not only diversifies India's security relationships at a time of flux, but also that European forces are less threatening to Beijing than those of the US or Japan" (Joshi, 2017). India began cooperating with the EU NAVFOR antipiracy operation in the Western Indian Ocean in 2009 immediately after its start, becoming one of the key partners. The EU launched the European Union Naval Force ATALANTA (EU NAVFOR) in December 2008 within the framework of European Common Security and Defence Policy (CSDP) and in accordance with relevant UN Security Council Resolutions (UNSCR) and International Law. In the "EU-India Agenda for Action" adopted at the EU-India summit in 2016, among the priorities there was to "deepen existing cooperation and consider cooperation in other areas mentioned in the EU-India Joint Action Plan, including promoting maritime security, freedom of navigation in accordance with international law (UNCLOS)" (EU-India Agenda for Action - 2020, 2016). "The EU has also requested India to participate in the EU-coordinated naval escort missions for the UN World Food Programme in the Indian Ocean as they travel to African states with food aid, recognizing India's capacities and intentions of becoming a security provider in the Indian Ocean" (Jain \& Sachdeva, 2019). In a joint statement at the $14^{\text {th }}$ India-EU Summit in 2017 in New Delhi, India and the EU reaffirmed their commitment to enhance maritime security cooperation in the Indian Ocean and beyond. They also underlined the importance of freedom 
of navigation, overflight and peaceful resolution of disputes, in accordance with the universally recognized principles of international law. Both leaders attached importance to the security, stability, connectivity and sustainable development of oceans and seas in the context of developing the "blue economy" (India-EU Joint Statement, 2017). The joint conference "Securing the maritime commons: India, the European Union and Indian Ocean maritime security", organized in New Delhi in 2019, started the cooperation between EU CRIMARIO and India's IFC-IOR (Information Fusion Centre - Indian Ocean Region), created in 2018. Both platforms have complementary goals that can serve as a channel of information sharing and confidence building, as well as help in building capacity among Indian Ocean nations and their extra-regional partners to face common challenges related to the movement of ships; thus the initiated cooperation was a signal that it is possible to upgrade the existing framework to an expanded maritime security dialogue.

The EU and India have cooperated in maritime governance for the past fifty years and have achieved several of the goals set up in their joint strategies and plans of actions. Those successes cover such areas of maritime governance as security of sea lanes for communication and fishery. Their achievements in decreasing the threats to the merchant fleet in the western part of the Indian Ocean region are widely acknowledged by other littoral states in the IOR. The activities of the Indian Ocean Tuna Commission are developing and the joint steps that are being taken to enhance the sustainable use of the living resources of oceans are significant, despite a lack of optimal efficiency. They have still not tapped the scale of the partnership potential in all elements of maritime governance, especially the blue economy. The inability to understand deep motives of each other, characteristic for the West-East dialogue (Zvyagina, 2015), could also, to some extent, explain the lack of robustness and limited scope in some areas of EU-India cooperation in the Indian Ocean Region.

\section{Conclusions}

In the light of Manners' and Diez' models, India and the EU have fulfilled the requirements for normative powers. Both entities apply normative justification rather than the use of material incentives or physical force. Their relations are "normatively sustainable" and "normatively explicable". Coherency and consistency of the principles promoted by them are the most decisive elements of their legitimacy. Their impact in shaping global affairs is embodied through their active role in creating an institutional framework with a democratic model of 
sustainable development and peaceful coexistence. In the changing interdependence of world affairs, they combine civilian power with economic and military. Both India and the EU, through their activities within the UNCLOS system and cooperation in the maritime domain, represent the normative power model in international affairs, following and promoting the universally recognized principles of the international law of the sea. Their impact on the implementation of goal 14 of the Agenda 21 is manifested in an institutional framework initiated and partially financed by them in the Indian Ocean region. They facilitate security in the sea lanes of communication in the Indian Ocean region essential for global trade involving other littoral countries and extra-regional naval powers. EU countries such as Germany, France and Spain, which have at their disposal the largest fleets and territories in IOR, also have developed their own maritime strategies in the Indian Ocean Region (Saint-Mézard, 2013), understanding the vitality of sea lanes of communications for their trade with India and other countries in Asia. Both India and the EU are active in maritime affairs in the areas of security, blue economy, sustainable development and marine safety in their respective regions. Despite those activities, the strategic partnership and China's growing assertiveness in the IOR, neither the EU nor India has extended their maritime cooperation beyond antipiracy operations (EU NAVFOR operation Atalanta) and fisheries (the Indian Ocean Tuna Commission). There is still untapped potential in all the mentioned areas of maritime governance. The convergence of interests achieved by the EU and India has reached a level when it can materialize programmes in the most democratic way and be beneficial for both through the creation of the optimal synergy of their activities in the maritime domain. That synergy needs better coordination and programmes which could be similar to the recent India-Japan initiative of the Asia-Africa Growth Corridor to constitute an alternative to the Belt and Road Initiative promoted by China. 


\section{REFERENCES}

Baruah, D. M., \& Joshi, Y. (2020, 29 May). India's policy on Diego Garcia and its quest for security in the Indian Ocean. Australian Journal of International Affairs. Retrieved from https://www.tandfonline.com/doi/full/10.1080/10357718.2020.1769550

Britsch, F. (2014). Indian Views of Europe's Role as Security Actor. Why the EU Needs to Change its Approach Towards India. Berlin: Friedrich Ebert Stiftung. Retrieved from https://library.fes.de/pdf-files/iez/10717.pdf

Bull, H. (1982). Civilian Power Europe: A Contradiction in Terms? Journal of Common Market Studies, 21(2), 149-170.

European Union External Action Service. (2016, 6 Oct). Indian Ocean Commission and the EU. Retrieved from https://eeas.europa.eu/diplomatic-network/indian-oceancommission/11295/ioc-and-eu_en

Cohen, S. (2001). India: Emerging Power. Washington, DC: Brookings Institution Press. Commission of the European Communities. (2007a, 10 Oct). An Integrated Maritime Policy for the European Union. Communication from the Commission to the European Parliament, the Council, the European economic and Social Committee and the Committee of the Regions, COM (2007) 0575. Retrieved from https://eur-lex. europa.eu/legal-content/EN/TXT/?uri=CELEX\%3A52007DC0575

Commission of the European Communities. (2007b, 10 Oct). Commission Staff Working Document, SEC (2007)1278. Retrieved from https://ec.europa.eu/transparency/ regdoc $/$ ?fuseaction=list\&coteId=2\&year=2007\&number=1278\&version=ALL\&lang uage $=\mathrm{pl}$

European Commission. (n.d.). Blue Growth. Retrieved from https://ec.europa.eu/maritimeaffairs/policy/blue_growth_en

Delegation of the European Union to India. (2018). The European Union and India: Trade and Investment 2017. New Delhi: Delegation of the European Union to India.

Delegation of the EU to India and Bhutan. (2006). India: Country Strategy Paper 2007-2013. EU EEAS. Retrieved from http://eeas.europa.eu/india/csp/07_13_en.pdf

Department of Animal Husbandry and Dairying. (2017). National Policy on Marine Fisheries. Ministry of Agriculture and Farmers' Welfare. Retrieved from http:// dahd.nic.in/news/notification-national-policy-marine-fisheries-2017

Department of Ocean Development of Government of India. (1982). The Ocean Policy Statement. Retrieved from https://moes.gov.in/writereaddata/files/OCEAN_POLICY_STATEMENT.pdf

Diez, T. (2005). Constructing the Self and Changing Others: Reconsidering Normative Power Europe. Journal of International Studies, 33(3), 613-636.

Duchêne, F. (1973). The European Community and the Uncertainties of Interdependence. London: Macmillan. 
EU-India Agenda for Action - 2020. (2016). EU-India Summit, Brussels, 30 March 2016. Retrieved from http://www.consilium.europa.eu/media/23671/20160330-agendaaction-eu-india.pdf

European Commission. (2017, 6 Oct). EU-India Summit: strengthening our strategic partnership and moving forward with our common agenda [Press release]. Retrieved from www.europa.eu/rapid/press-release_IP-17-3728_en.pdf

Germond, B. (2015). The Maritime Dimension of European Security: Seapower and the European Union (pp. 19-32). Palgrave Studies in European Union Politics. Basingstoke: Palgrave Macmillan.

India-EU Joint Statement, 14th India-EU Summit, New Delhi, 2017. (2017). Retrieved from www.consilium.europa.eu/media/23515/eu-india-joint-statement.pdf

The India-EU Strategic Partnership. Joint Action Plan. (2005, 7 Sep). 11984/05, Press 223. Brussels: Council of the European Union. Retrieved from https://www.europarl. europa.eu/cmsdata/122865/86130.pdf

Indian Ocean Tuna Commission. (2016). Report of the 2nd IOTC Performance Review, OTC-2016-PRIOTC02-R[E]. Retrieved from http://www.iotc.org/documents/report2nd-iotc-performance-review.

Jain, R. K. (2014). India-EU Strategic Partnership: Perceptions and Perspectives. NFG Working Paper Series 10. Berlin: Freie Universität Berlin. Retrieved from http://www. asianperceptions.eu/nfg-working-papers

Jain, R. K., \& Pandey, S. (2019). The EU Global Strategy and EU-India Relations: A Perceptions Study. In N. Chaban \& M. Holland (Eds.), Shaping the EU Global Strategy: Partners and Perceptions (pp. 101-126). Brussels: Palgrave Macmillan.

Jain, R. K., \& Sachdeva, G. (2017). India-EU strategic partnership: a new roadmap. Asia Europe Journal. Studies on Common Policy Challenges, 17(3), 309-325. DOI: 10.1007/ s10308-019-00556-0

Jain, R. K. (Ed.). (2015). The European Union and South Asia. New Delhi: KW Publishers Pvt Ltd.

Joshi, S. (2017). The prospects for EU-India security cooperation. European View, 16(2) 271-279. DOI: https://doi.org/10.1007/s12290-017-0453-7

Kammerling, S., \& Pandit, P. (2019). Seizing the Momentum: Avenues for EU-Indian Maritime Cooperation in a Connectivity Context. Clingendael Policy Brief - Institute of International Relations. Retrieved from https://www.clingendael.org/sites/ default/files/2019-10/Seizing\%20the\%20momentum_\%20avenues\%20for\%20EU indian\%20maritime\%20cooperation.pdf

Kavalski, E. (2016) The EU-India strategic partnership: neither very strategic, nor much of a partnership. Cambridge Review of International Affairs, 29(1), 192-208.

Kavalski, E. (2008). Venus and the Porcupine: Assessing the European Union-India Strategic Partnership. South Asian Survey, 15(63), 75.

Khurana, G. (2009). India's sea-blindness. Indian Defence Revue, 24. Retrieved from http://www.indiandefencereview.com/news/?page=15\&ipage $=226$ 
Kumar, R. (2008), India as a Foreign Policy Actor - Normative Redux. European Security Forum Working Paper, 29, 27-28. Retrieved from https://books.google.pl/books? $\mathrm{id}=$ rLfFUXli5BoC\&printsec $=$ frontcover\&hl=pl\&source=gbs_ge_summary_r\&cad $=0 \# \mathrm{v}=$ onepage $\& \mathrm{q} \& \mathrm{f}=$ false

Manners, I. (2000). Normative Power Europe: A Contradiction in Terms. Copenhagen: Copenhagen Peace Research Institute.

Manners, I. (2006). Normative power Europe reconsidered: beyond the crossroads. Journal of European Public Policy, 13(2), 194. Retrieved from https://www.tandfonline.com/doi/abs/10.1080/13501760500451600

Manners, I. (2009). The Concept of Normative Power in World Politics. Copenhagen: Danish Institute for International Studies.

Michael, A. (2016, 20 Oct). India and the EU in the Indian Ocean Maritime Security as Catalyst for Cooperation. FEPS Policy Brief. Brussels: Carnegie India and Foundation for European Progressive Studies. Retrieved from https://www.feps-europe.eu/ Assets/Publications/PostFiles/448_1.pdf

Modi, N. (2017, 17 Jan). Inaugural Address by Prime Minister at Second Raisina Dialogue, New Delhi. Retrieved from https://mea.gov.in/Speeches Statements.ht

Modi, N. (2015, 12 Nov). PM Modi in UK: Full text of PM Modi's speech at British Parliament. India Today. Retrieved from https://www.indiatoday.in/india/story/pmmodi-in-uk-full-text-of-pm-modis-speech-at-british-parliament-272559-2015-11-12

Mohan, C. R. (2004). Crossing the Rubicon: The Shaping of India's New Foreign Policy. London: Palgrave.

Permal, S. (2014). Indo-Pacific Region: Perspectives from Southeast and East Asia. In R. Bhatia \& V. Sakhuja. (Eds.), Indo Pacific Region: Political and Strategic Prospects (pp. 67-85). New Delhi: Vij Books India Pvt Ltd, Indian Council of World Affairs.

Puthucherril, T. G. (2015). A Case Study of India's Policy and Legal Regimes on Ocean Governance. In B. Cicin-Sain, D. L. VanderZwaag \& M. C. Balgos (Eds.), Routledge Handbook on National and Regional Ocean Policies. London and New York: Routledge.

Ram, A. N. (2015). India, the European Union and South Asia. In R. K. Jain (Ed.), The European Union and South Asia (pp. 1-9). New Delhi: KW Publishers Pvt Ltd. Saint-Mézard, I. (2013). The French strategic vision of the Indian Ocean. Journal of the Indian Ocean Region, 9(1), 53-68.

Saran, S., Pejsova, E., Price, G., Gupta, K., \& Wilkins, J.-J. (2016). Prospects for EU-India Security Cooperation. New Delhi: Observer Research Foundation.

Schoettli, J. (2014). India EU Strategic Relations: Prospects for Cooperation in the Indian Ocean. In S. O. Wolf, P. Casaca, A. J. Flanagan \& C. Rodrigues (Eds.), The Merits of Regional Cooperation. The Case of South Asia (pp. 119-130). Heidelberg: Springer.

Schoettli, J. (2019). "Security and growth for all in the Indian Ocean" - maritime governance and India's foreign policy. India Review, 18(5), 569. Retrieved from https:// 
www.tandfonline.com/doi/abs/10.1080/14736489.2019.1703366?scroll=top\&needAc cess $=$ true\&journalCode $=$ find 20

Singh, A. K. (2007). India's security concerns in the Indian Ocean region. New Delhi: Har-Anand Publications.

Singh, M. (2019). The European Union and the Asian Security Order: Aspirations and Strategic Interests. In G. Sachdeva (Ed.), Challenges in Europe: Indian Perspectives (pp. 127-145). Singapore: Palgrave Macmillan.

Subrahmanyam, J. (2016, 2 Mar). Speech by Foreign Secretary at Raisina Dialogue in New Delhi. Ministry of External Affairs of India. Retrieved from www.mea.gov.in/ Speeches-Statements.htm

Techera, E. J. (2018). Supporting blue economy agenda: fisheries, food security and climate change in the Indian Ocean. Journal of the Indian Ocean Region, 14(1), 8. Retrieved from https://www.tandfonline.com/doi/full/10.1080/19480881.2017.1420 579

Zvyagina, D. (2015). The Measure of Trust in International Relations. West-East Relations Case. The Copernicus Journal of Political Studies, 7(1), 35. Retrieved from https://apcz.umk.pl/czasopisma/index.php/CJPS/article/view/cjps.2015.01.02/15785 